\title{
PEMANFAATAN SISTEM INFORMASI UNTUK PENGELOLAAN MEDIK DAN JASA KESEHATAN DI KLINIK
}

\author{
Henny Hendarti ${ }^{1}$; Seplita Anggita ${ }^{2}$; Wina ${ }^{3}$ \\ 1,2,3 Jurusan Komputerisasi Akuntansi, Fakultas Ilmu Komputer, Universitas Bina Nusantara, \\ Jln. K.H. Syahdan No.9, Palmerah, Jakarta Barat 11480 \\ henny@binus.edu
}

\begin{abstract}
Article presented an information system development which can facilitate the doctors and nurses at clinic in managing outpatient and reporting data quickly, accurately, and effectively. Before using a computerized system, all data recording was still done conventionally using paper media. The research method used was an analysis and designing method, interviews, library research, and field study as to do an observation. The analysis and designing method, which was proposed, used an object-oriented concept and presented through notation of Unified Modeling Language (UML). The research results showed that a clinic needs a new system which can facilitate the doctors and nurses in processing operational data, such as medical record data and other data relating to the outpatient. It can be concluded that with the presence of the information system, it is expected that it can facilitate the information needs by using a computerized system.
\end{abstract}

Keywords: system utillty, information system, medical management, clinic

\section{ABSTRAK}

Artikel menggambarkan pengembangan suatu sistem informasi yang dapat mempermudah dokter dan perawat pada klinik dalam mengelola data rawat jalan dan pelaporan dengan cepat, tepat, dan efektif. Sebelum menggunakan sistem terkomputerisasi, semua pencatatan data masih dilakukan secara konvensional menggunakan media kertas. Metode penelitian yang digunakan adalah metode analisis dan perancangan, wawancara, studi pustaka dan studi lapangan seperti dengan mengadakan pengamatan. Metode analisis dan perancangan yang diajukan, menggunakan konsep berorientasi objek dan dipresentasikan melalui notasi Unified Modelling Language (UML). Hasil penelitian menunjukkan bahwa sebuah klinik membutuhkan suatu sistem baru yang dapat mempermudah dokter dan perawat dalam mengolah data operasional, misalnya data rekam medik dan data lain yang berhubungan dengan rawat jalan. Disimpulkan dengan adanya sistem informasi, diharapkan dapat memenuhi kebutuhan informasi dengan menggunakan sistem terkomputerisasi.

Kata kunci: analisis, perancangan, sistem informasi, pengelolaan medik, klinik

\section{PENDAHULUAN}

\section{Latar Belakang}

Teknologi informasi adalah teknologi yang membantu kita dalam memproses data untuk mendapatkan informasi. Teknologi informasi ini pada awalnya diperuntukan bagi tujuan dan departemen tertentu. Namun, dengan semakin berkembangnya teknologi informasi, saat ini penggunaannya sudah menjadi hal yang umum di perusahaan swasta di bidang perdagangan maupun jasa, seperti halnya pelayanan jasa kesehatan. Perkembangan teknologi ini sangatlah luas dan menjangkau berbagai bidang. Tapi pada akhirnya, semua itu tetap mengarah pada satu tujuan yang sama, yaitu meningkatkan kecepatan, akurasi, dan kemudahan. "Growth of information technology can improve performance and enable various activities can be executed swiftly, precisely and accurate, so that finally will improve productivity. Growth of information technology show the popping out of various activity type being based on this technology, like e-government, e-commerce, e-education, e-medicine, e-laboratory, and other, which is all the things have electronics based".

Hambatan dalam pelayanan kesehatan adalah pengelolaan data rumah sakit yang sangat besar, baik data medik pasien maupun data administrasi yang dimiliki oleh rumah sakit, sehingga mengakibatkan hal-hal sebagai berikut.
Pertama adalah redudansi data. Pencatatan data yang berulang-ulang menyebabkan duplikasi data, sehingga kapasitas yang diperlukan membengkak dan pelayanan menjadi lambat. Kedua adalah unintegrated data. Penyimpanan data yang tidak terpusat menyebabkan data tidak sinkron, sehingga informasi pada masing-masing bagian mempunyai asumsi yang berbeda-beda. Ketiga adalah human error. Proses pencatatan yang dilakukan secara manual menyebabkan terjadinya kesalahan pencatatan yang semakin besar. Keempat adalah terlambatnya informasi. Dikarenakan dalam penyusunan informasi harus direkap secara manual, maka penyajian informasi menjadi terlambat dan kurang dapat dipercaya kebenarannya.

Keberadaan "Sistem Informasi Manajemen Rumah Sakit" sangat dibutuhkan sebagai salah satu strategik manajemen dalam meningkatkan mutu pelayanan kesehatan dan memenangkan persaingan bisnis.

\section{Ruang Lingkup Penelitian}

Adapun ruang lingkup yang akan dirancang adalah: pendataan pasien, mencakup rekam medis pasien selama menjalani konsultasi rawat jalan; pencatatan transaksi pemeriksaan; pendataan stok obat; dan pembuatan laporan bulanan. 


\section{Tujuan dan Manfaat}

Penelitian ini ditujukan untuk merancang sistem informasi yang meliputi: perancangan sistem informasi klinik, penyimpanan data pasien dan penyimpanan data obat, serta merancang sistem informasi klinik yang memadai untuk mengatasi permasalahan dan kekurangan di dalam klinik perusahaan. Selain itu, ada manfaat yang ingin dicapai dalam penelitian, yaitu: klinik dapat meningkatkan kinerja sistem yang sedang berjalan, sehingga lebih efektif dan efisien dalam penggunaannya; serta untuk memecahkan masalah yang dihadapi klinik dalam pembuatan laporan harian penggunaan obat, laporan bulanan dan harian penyakit pasien, serta pencatatan stok obat.

\section{PEMBAHASAN}

\section{Metode}

Metode yang digunakan dalam penyusunan penelitian ini adalah metode kepustakaan dan analisis.

\section{Metode Kepustakaan}

Penulis akan mengumpulkan teori dan informasi dari buku, hasil penelitian ilmiah, dan sumber lainnya.

\section{Metode Analisis}

Analisis sistem dilakukan dalam 4 tahap sebagai berikut. Pertama adalah survei terhadap sistem yang sedang berjalan. Mengumpulkan data dan informasi langsung dari tempat penelitian, yang dilakukan dengan cara interview atau wawancara langsung dengan dokter dan perawat yang bekerja di klinik; analisis terhadap hasil survei; serta melakukan analisis terhadap hasil survei yang telah diperoleh. Kedua adalah identifikasi kebutuhan informasi, yakni dengan mengidentifikasi kebutuhan informasi yang diperlukan untuk pengembangan sisfo di klinik. Ketiga adalah identifikasi persyaratan sistem, yakni dengan mengidentifikasi persyaratan sistem yang diperlukan, untuk perancangan sistem yang diusulkan untuk klinik. Keempat adlah metode perancangan. Metode analisis dan perancangan yang digunakan adalah object oriented analysis and design, yaitu: perancangan Rich Picture, perancangan Class Diagram, perancangan Use Case Diagram, perancangan Database, perancangan formulir, perancangan layer, perancangan laporan, dan perancangan Navigation Diagram.

\section{Landasan Teori}

Berikut ini adalah landasan teori yang digunakan di dalam penelitian ini. Menurut www.wikipedia.org, sistem informasi rumah sakit atau dapat disebut juga Clinical Information System (CIS) adalah sebuah sistem informasi terintegrasi yang didesain untuk menangani semua kegiatan administratif dan finansial dari rumah sakit. Sistem ini mencakup semua pemrosesan informasi. Analisis sistem (system analisist) didefinisikan oleh Jogiyanto (1999: 129) sebagai penguraian dari suatu sistem informasi yang utuh ke dalam bagian-bagian komponennya, dengan maksud untuk mengidentifikasi dan mengevaluasi permasalahan, kesempatan, hambatan yang terjadi dan kebutuhan yang diharapkan, sehingga dapat diusulkan perbaikannya.

Perancangan sistem adalah tahap setelah analisis dari siklus pengembangan sistem; pendefinisian dari kebutuhankebutuhan fungsional; persiapan untuk rancang bangun implementasi; menggambarkan bagaimana suatu sistem dibentuk; yang dapat berupa penggambaran, perencanaan, dan pembuatan sketsa atau pengaturan dari beberapa elemen, yang terpisah dalam satu kesatuan utuh dan berfungs termasuk menyangkut mengkonfigurasi dari komponenkomponen perangkat lunak dan perangkat keras dari suatu sistem (Jogiyanto, 1999: 197).

Metode analisis dan desain berorientasi object adalah metode yang menggunakan object dan class sebagai konsep utama dan membangun prinsip umum utama untuk analisis dan desain (Mathiassen, Madsen, Nielsen, dan Stage, 2000: 3). Sedangkan rich picture adalah suatu gambar informal yang mempresentasikan situasi tampilan user dari suatu sistem (Mathiassen, Madsen, Nielsen, dan Stage, 2000: 26-27).

Event adalah sesuatu yang terjadi pada waktu tertentu (Jones dan Rama, 2006: 4). Workflow tabel adalah sebuah tabel dengan dua kolom yang mengidentifikasikan semua aktor dan aktifitas yang dilakukan dalam sebuah proses (Jones dan Rama, 2006: 73). Ada 2 tipe activity diagram (Jones dan Rama, 2006: 61), yaitu: overview activity diagram mempresentasikan gambaran secara umum dari proses bisnis dengan mendokumentasikan event kunci, urutan dari eventevent ini dan arus informasi di antara event-event; detailed activity diagram hampir sama dengan suatu peta dari sebuah kota. Menyediakan representasi yang lebih terperinci dari aktivitas yang berhubungan dengan satu atau 2 event, yang ditampilkan pada overview diagram. Database management system adalah koleksi program yang memungkinkan anda untuk memasukkan, mengorganisasikan dan memilih informasi dari sebuah Database (Jones dan Rama, 2006: 201).

UML class diagram adalah gambaran mengenai sekumpulan class dan hubungan antar class yang terstruktur (Mathiassen, Madsen, Nielsen, dan Stage, 2000: 69-70). Use case diagram adalah suatu pola interaksi antara sistem dan actor dalam application domain (Mathiassen, 2000: 19). Navigation diagram adalah jenis khusus dari statechart diagram yang berfokus pada dinamika keseluruhan dari tampilan layar. Diagram ini menunjukan window-window yang bersangkutan dan perpindahan di antara mereka (Mathiassen, Madsen, Nielsen, dan Stage, 2000, p343).

Formulir adalah secarik kertas yang memiliki ruang untuk diisi. Formulir sering pula disebut dengan dokumen (Mulyadi, 2001: 75). Desain dialog layar terminal merupakan rancang bangun dari percakapan antara pemakai sistem (user) dengan komputer (Jogiyanto, 1999: 391). Siklus hidup pengembangan sistem (SHPS) adalah kerangka kerja terstruktur, terdiri dari proses yang berurutan yang mana sistem informasi tersebut dibangun (Turban et al., 2003: 463). Reorder Point (ROP) adalah metode untuk menentukan titik pemesanan kembali. Kegunaan utama dari metode Reorder Point ini adalah untuk tetap dapat meemenuhi permintaan pasar selama dalam waktu tenggang pemesanan. Metode Reorder Point ini implementasinya memerlukan data mengenai rata-rata penjualan harian dan standar deviasi, yang digunakan sebagai ukuran pengamanan stok untuk memenuhi permintaan selama masa tenggang pemesanan barang (http:// digilib.petra.ac.id).

\section{Siklus Hidup Pengembangan Sistem (SHPS)}

Berdasarkan Turban et al. (2003: 464), Siklus Hidup Pengembangan Sistem (SHPS) dibagi menjadi 8 tahapan sebagai berikut. Pertama adalah investigasi sistem. Tugas yang paling penting dalam tahap ini adalah belajar. Belajar dapat menentukan suksesnya proyek sistem perkembangan dan memperkirakan proyek teknikal, ekonomi, dan bertingkah laku. Belajar dapat mencegah organisasi berbuat kesalahan yang besar. Kedua adalah analisis sistem. System analyis adalah pemeriksaan masalah bisnis yang direncanakan organisasi agar dapat diselesaikan oleh organisasi. Tahap ini menjelaskan masalah bisnis, mengidentifikasi penyebabnya, menspesifikasi solusi, dan mengidentifikasi syarat informasi yang solusinya harus memuaskan. Ketiga adalah desain sistem. Sistem desain menggambarkan apa yang harus sistem lakukan untuk menyelesaikan masalah bisnis dan menggambarkan sistem akan menyelesaikan tugasnya. 
Keempat adalah pemrograman sistem. Sistem perkembangan menggunakan rancangan spesifikasi untuk memperoleh software yang diberikan untuk sistem, untuk bertemu dengan fungsional objek dan menyelesaikan masalah bisnis. Jika organisasi memutuskan membuat software sendiri, lalu pemrograman meliputi penterjemahan dari sistem aplikasi ke kode komputer. Proses ini cukup panjang dan memakan waktu yang lama. Dalam sebuah percobaan untuk mengatasi kekakuan proses pemrograman, programer menggunakan teknik pemrograman terstruktur.

Kelima adalah pengujian sistem. Testing memeriksa apakah kode komputer akan menghasilkan hasil yang diharapkan dan diinginkan dengan kondisi tertentu. Testing dirancang untuk mendeteksi kesalahan pada kode komputer. Keenam adalah implementasi sistem. Implementation adalah proses mengubah sistem lama ke sistem baru. Ketujuh adalah operasi sistem. Operasi sistem digunakan untuk membantu proses bisnis dan juga memudahkan untuk memperbaiki sistem bila sistem tidak berjalan dengan baik, serta untuk mengetahui apakah sistem tersebut dapat membantu dalam pencapaian tujuan utama suatu perusahaan atau organisasi. Kedelapan adalah maintenance. Sistem memerlukan beberapa tipe dari maintanance. Tipe pertama adalah dari kesalahan program, proses yang berlangsung seluruhnya dari sistem. Tipe kedua adalah memperbaharui sistem untuk membuat perubahan dalam kondisi bisnis. Tipe ketiga meliputi menambah keuntungan baru sistem tanpa menggangu sistem operasi.

\section{Tipe-tipe Aplikasi Kontrol}

Tipe-tipe dari aplikasi kontrol terdiri dari: kontrol workflow, kontrol input, kontrol umum, dan review kinerja (Jones dan Rama, 2006: 123-124).

\section{Kontrol Workflow}

Kontrol workflow adalah kontrol yang mengendalikan proses ketika bergerak dari satu event ke event berikutnya. Kontrol workflow mengeksploitasi hubungan antar event dan berfokus pada tanggung jawab pada event, urutan event, dan alur informasi antar event dalam suatu proses bisnis. Kontrolkontrol yang termasuk dalam kontrol workflow antara lain sebagai berikut.

Pertama adalah pembagian tugas. Pembagian tugas antara internal agent merupakan konsep utama dalam merancang aktivitas kontrol internal. Kontrol internal menjadi lebih kuat ketika individu yang terpisah ditempatkan pada otorisasi, eksekusi, dan pencatatan transaksi.

Kedua adalah penggunaan informasi dari event sebelumnya untuk mengontrol aktivitas. Informasi dari aktivitas sebelumnya sering digunakan untuk mengontrol aktivitas bisnis. Dengan memanggil kembali informasi dari aktivitas sebelumnya, secara otomatis sistem dapat menjalankan beberapa aktivitas peninjauan.

Ketiga adalah kebutuhan event yang berurutan. Secara khusus, urutan di mana file maintanance dan event lainnya terjadi, penting untuk dipertimbangkan dalam merancang sebuah sistem informasi akuntansi. Dalam menghindari pembelian yang tidak sah, prosedur pemeliharaan supplier yang tepat harus digunakan untuk menyediakan supplier yang sah untuk organisasi. Dengan demikian, kontrol dalam event selanjutnya dapat digunakan untuk memastikan pembelian berasal dari supplier yang sah.

Keempat adalah follow up atas event. Sebuah organisasi seharusnya memiliki cara yang otomatis atau manual untuk melihat kembali transaksi yang belum selesai. Ketika sebuah event terjadi, biasanya akan memberikan harapan event lainnya pada masa mendatang. Sebagai contoh, ketika pemesan menyerahkan daftar permintaan, kita mengharapkan adanya event persetujuan yang diikuti oleh pencatatan daftar permintaan. Proses ini dapat dirancang untuk membantu karyawan mengawasi, apakah event yang diharapkan telah terjadi dan menindaklanjuti berdasarkan event yang diharapkan.

Kelima adalah pre-numbered document. Pre-numbered document menyediakan kesempatan untuk mengontrol event. Memeriksa urutan dokumen bernomor dapat membantu memastikan semua event dijalankan dan dicatat dengan tepat.

Keenam adalah merekam internal agent yang memproses event. Internal agent ditunjuk bertanggung jawab pada kebanyakan event. Sehingga dengan mencatat internal agent yang bertanggung jawab atas sebuah event, dapat diketahui agent yang terlibat dalam event dan melihat apakah tanggung jawab tersebut dipelihara untuk individu tersebut. Sebagai contohnya, activity diagram menunjukkan pemesan, sekretaris dan pengawas yang terlibat dalam memutuskan, menyetujui, dan mencatat pesanan.

Ketujuh adalah batasan akses atas aset dan informasi. Langkah penting untuk melindungi aset seperti kas, persediaan, perlengkapan, dan data adalah dengan membatasi akses hanya pada karyawan yang memerlukannya untuk tugas-tugas mereka. Activity diagram dapat digunakan sebagai media untuk menganalisis dan mengontrol akses ke informasi. Sebagai contoh, kita dapat mengidentifikasi user yang melakukan activity yang membutuhkan informasi dari file tertentu, dan membuat atau menggunakan dokumen atau laporan. Control terhadap aset dapat mengurangi kemungkinan karyawan memasuki sistem dan memasukkan pesanan yang tidak sah.

Kedelapan adalah rekonsiliasi record dengan aset fisik. Perhitungan fisik secara berkala pada persediaan adalah control penting yang digunakan oleh organisasi. Control tersebut penting untuk memastikan jumlah persediaan yang tercatat berdasarkan tanda terima, penjualan, dan data persediaan lainnya sama dengan persediaan yang sesungguhnya tersedia.

\section{Kontrol Input}

Kontrol input adalah kontrol yang digunakan untuk mengendalikan input data ke sistem komputer. Kontrol input terdiri dari: drop-down dan look-up menu; record checking; konfirmasi data dengan menampilkan data yang berhubungan dengan data yang dimasukkan user; referential integrity control untuk memastikan event record terhubung dengan Master record yang tepat; aturan validasi untuk membatasi data yang bisa dimasukkan pada nilai tertentu; penggunaan default sebelum data dimasukkan; computer generated value; batch control total sebelum data entry dibandingkan dengan print out setelah data entry; review report yang diedit sebelum diposting; serta exception report di mana mendaftar kasus di mana default diganti dengan nilai yang tidak biasa.

\section{Kontrol Umum}

Kontrol umum terbagi dalam 4 katagori yang terdiri dari: perencanaan sistem informasi, pengorganisasian fungsi IT, mengidentifikasi dan membangun solusi IT, serta mengimplementasikan dan mengoperasikan sistem akuntansi.

\section{Review Kinerja}

Review kinerja dibagi ke dalam 3 kategori yaitu: mereview anggaran, peramalan masa depan, standar atau hasil sebelumnya melalui file maintenance; menggunakan report untuk membandingkan dengan hasil dari anggaran, ramalan masa depan, standar dan hasil sebelumnya; serta aksi pengoreksian, jika diperlukan untuk meningkatkan kinerja atau mengubah tabel Master. 


\section{Uraian Proses Bisnis}

Sistem pemeriksaan di dalam klinik yang sedang berjalan pada klinik, pendaftaran pasien, hingga pemberian obat bersifat konvesional (file-based-system). Maksud dari konvesional itu sendiri adalah pendokumentasian data pasien (rekam medik) masih dilakukan pencatatan manual (menggunakan media alat tulis). Untuk laporan harian maupun bulanan mengenai transaksi yang terjadi di klinik, juga menggunakan pembukuan, tidak menggunakan komputerisasi. Kondisi penyimpanan data dan laporan yang masih menggunakan pembukuan semacam ini terkesan sangat lambat, dalam hal proses pencarian data rekam medik pasien dan proses pengisian laporan harian maupun bulanan.

\section{Perumusan Masalah}

Berdasarkan hasil analisis dari prosedur kegiatan di klinik yang sedang berjalan saat ini, maka ditemukan beberapa masalah, yaitu: proses untuk mencari data pasien saat proses pendaftaran sulit dilakukan, pembuatan laporan rutin menjadi lebih sulit dan membutuhan waktu yang lebih lama, dokter tidak tahu apakah obat masih tersedia atau tidak, serta untuk medical record keluarga karyawan, kartu statusnya digabungkan dengan kepala keluarga yang memiliki Nomor Induk Karyawan.

\section{Usulan Pemecahan Masalah}

Berdasarkan analisis terhadap permasalahan yang dihadapi saat ini oleh perusahaan, maka diusulkan suatu pemecahan masalah, yaitu perancangan sistem informasi klinik. Perancangan ini terdiri dari tampilan yang memudahkan dokter untuk mengakses medical record karyawan dan pembuatan laporan, serta penyimpanan data dalam aplikasi Database untuk menggantikan sistem konvensional atau file based sistem yang mempunyai permasalahan yang telah disebutkan di atas.

\section{Standar dan Prosedur Sistem Informasi}

Ketika aplikasi dimulai, maka akan muncul form login. Untuk dapat mengakses ke dalam sistem informasi klinik, calon user harus memasukkan user name dan password (kata sandi). Jika user name atau password yang dimasukkan salah, maka akan muncul peringatan yang bertuliskan "user name atau password salah!". Untuk keluar dari form login ini, yang harus dilakukan adalah menekan tombol Exit atau Cancel.

Setelah user berhasil login, maka akan muncul layar menu utama yang berisikan menu-menu seperti: Master, Transaksi, Grafik, Laporan, dan Keluar. Jika ada terjadi kesalahan dalam pencatatan, maka akan mucul pesan yang berisikan kesalahannya dan user diminta untuk memperbaikinya. Hal ini berlaku untuk semua form yang ada.

Berikut ini akan dibahas satu persatu fungsi dan cara pengunaan fasilitas dalam setiap menu yang tersedia.

\section{Menu Master}

Menu Master berisikan beberapa bagian yaitu: Master karyawan, yang berisi data semua karyawan yang bekerja pada perusahaan; Lalu Master keluarga, yang berisi data pribadi anggota keluarga karyawan perusahaan yang pernah melakukan transaksi di klinik; Master dokter, berisi data dokter yang bekerja di klinik. Master obat berisikan data-data obat dan stok obat yang tersedia di klinik; Master pemeriksaan, berisikan data-data diagnosis penyakit. Form Master karyawan dapat diakses dengan memilih menu "Master" lalu "Master Karyawan". Fungsinya adalah untuk menambah, mengubah atau menghapus data karyawan yang terdaftar. Untuk menambah ke dalam Database karyawan, user memilih button "New" atau bisa langsung memilih form "General", lalu mengisi informasi yang dibutuhkan pada field yang ada. Setelah selesai tekan tombol "Simpan" untuk menyimpan data. Pada saat pengisian data di dalam Master, data harus lengkap diisi. Bila tidak, akan muncul message box untuk menampilkan informasi bahwa "Data harus lengkap diisi". Untuk mengedit data, user harus memilih dulu data mana yang akan diedit, kemudian tekan tombol "Edit". Untuk menghapus data, user harus memilih dahulu data mana yang akan dihapus, kemudian tekan tombol "Hapus". Untuk keluar dari form ini, user bisa langsung menekan tombol "Keluar".

\section{Menu Transaksi}

Menu transaksi terdiri dari transaksi pasien dan rekaman medik. Di dalam menu transaksi pasien dan rekaman medik, terdapat 4 bagian yaitu: Overview, General, Pemeriksaan, dan Penggunaan Obat. User memilih "General" yaitu merupakan form untuk meng-input data pasien yang akan melakukan pemeriksaan. User mengisi field berupa data-data pasien dan bisa memilih "status" (karyawan/keluarga). Setelah mengisi semua field, user menekan tombol "Simpan". Sistem akan menampilkan bagian "Overview" yang berisi daftar pasien yang akan diperiksa.

Ketika memulai pemeriksaan, user mengklik 2 kali pada nama pasien. Tampilan akan menunjukkan rekaman medik pengobatan pasien. Setelah pemeriksaan, user menginput hasil diagnosis pasien dan terapi yang diberikan. Setelah itu, memilih bagian "Obat" untuk meng-input obat yang akan diberikan kepada pasien. User memilih tombol "+" untuk menambah record pemeriksaan dan pemberian obat yang akan tersimpan dalam rekam medik pasien.

\section{Menu Grafik}

Menu ini memungkinkan user untuk melihat data laporan berupa grafik. Menu ini hanya dapat dilihat saja, namun tidak dapat dicetak. Untuk mengakses menu ini, user hanya memilih laporan apa yang ingin dia lihat, grafik penyebaran penyakit atau grafik kunjungan pasien, setelah itu input periode yang diinginkan. Dalam memilih jenis grafik, sistem menyediakan tampilan grafik berupa line, bar, dan $3 D$ line.

\section{Menu Laporan}

Menu laporan berisikan beberapa bagian seperti: laporan rekam medik, yang merupakan laporan rekam medik setiap pasien di klinik, ringkasan pemeriksaan, dan terapi yang diberikan. Untuk mencetak laporan ini, user perlu memasukkan kode pasien. Lalu secara otomatis akan menampilkan data pasien tersebut dan hasil pemeriksaannya; laporan pemakaian obat, yang berfungsi untuk mencetak laporan pemakaian obat oleh tiap pasien; laporan kartu stok obat, yang berfungsi untuk mencetak laporan stok obat pada persediaan. Dalam laporan ini, juga ditunjukkan stok minimum obat, dan apakah obat sudah mendekati ROP atau belum; serta laporan penyakit terbanyak, yang berfungsi untuk mencetak laporan diagnosis penyakit terbanyak sesuai periode yang diinginkan user.

Cara penggunaan ketiga laporan tersebut hampir sama, yakni dengan cara memasukkan periode laporan yang ingin dicetak, kemudian tekan cetak untuk melihat hasil laporan atau mencetak laporan. Message box akan tampil ketika user ingin mencetak laporan dan memasukkan periode, namun data pada periode tersebut tidak tersedia.

\section{Menu keluar}

Menu keluar digunakan untuk keluar dari aplikasi dan kembali ke form login. 


\section{Overview Rancangan Sistem Informasi}

Berawal saat pasien datang, pasien akan mendatangi perawat. Perawat akan mencatat nomor induk atau nama pasien ke dalam transaksi pasien dan rekam medik dalam sistem bila pasien sudah pernah datang, perawat tinggal menanyakan nama pasien, dan akan men-search di dalam Master pasien. Perawat juga akan memeriksa tekanan darah pasien dan berat badan pasien. Dokter akan masuk ke dalam sistem, lalu pilih menu pasien dan rekam medik. Dokter akan memulai pemeriksaan. Setelah itu, dokter akan meng-input diagnosis pasien, terapi yang diberikan dan pemberian obat ke dalam medical record dalam sistem. Setelah pemeriksaan selesai pasien akan kembali ke perawat dan perawat akan mengecek obat apa yang diberikan dokter, lalu perawat akan memberikan obat kepada pasien. Perawat juga akan mencetak transaksi penggunaan obat pasien, pasien akan menandatangani, lalu perawat akan mengarsipnya.

Apabila pasien hanya ingin meminta obat, perawat akan meng-input transaksi penggunaan obat dan mencetaknya, lalu pasien akan menandatanganinya. Untuk pembuatan laporan, dokter akan masuk ke sistem, lalu memilih menu laporan stok obat dan laporan penyakit bulanan pasien, kemudian mencetaknya. Dokter juga bisa melihat grafik kunjungan pasien dan penyebaran penyakit dalam 3 bentuk yaitu: grafik line, bar, dan 3D line.

\section{PENUTUP}

\section{Kesimpulan}

Berdasarkan hasil analisis yang telah dilakukan, dapat diambil beberapa kesimpulan sebagai berikut. Pertama, pada sistem rawat jalan yang berjalan, pasien harus menunggu perawat untuk mencari medical record secara manual. Pada sistem yang diusulkan, pasien hanya menyebutkan kode karyawannya. Perawat akan memasukkan ke sistem, dan pasien dapat langsung menemui dokter karena medical record pasien ada di dalam sistem tersebut. Jadi, dokter dapat langsung melihat saja.

Kedua, dalam pembuatan laporan dokter harus mengecek rangkuman transaksi harian, dan mengolah datadata tersebut sendiri. Dengan diterapkannya sistem informasi yang dirancang, dokter hanya tinggal meng-input periode kapan yang dia butuhkan dan laporan bisa langsung tercetak. Dengan laporan tersebut, dapat membantu dokter untuk menilai jenis penyakit apa yang paling banyak diderita pasien, laporan obat yang mendekati ROP, dan kunjungan pasien ke klinik.

Ketiga, dengan sistem informasi yang terkomputerisasi pada klinik, memudahkan dokter dalam pengambilan keputusan. Dengan melihat laporan pemakaian obat, dokter bisa menentukan obat apa yang paling banyak digunakan. Dengan melihat laporan penyakit, dokter bisa melihat trend penyakit apa yang paling banyak diderita oleh pasien dalam periode tertentu, sehingga bisa menyiapkan pencegahan penyakit.

Keempat, sistem pemeriksaan dalam klinik yang sedang berjalan, untuk pendaftaran pasien hingga pemberian obat, pemeriksaan harian dan bulanan mengenai transaksi yang digunakan di klinik, juga masih menggunakan pembukuan. Dengan menggunakan sistem komputerisasi yang diusulkan, maka semua pencatatan rekam medik dapat dicari dengan cepat.

Kelima, penyimpanan data dalam bentuk kumpulan dokumen memiliki resiko yang besar terhadap kemungkinan terjadinya hilang data, yang disebabkan oleh kelalaian manusia, dan kondisi fisik dokumen yang mudah rusak. Dengan diterapkannnya sistem komputerisasi, maka dokumen tersebut tidak akan rusak dan mempunyai Database dokumen tersebut.

Keenam, untuk medical record keluarga karyawan, kartu statusnya digabungkan dengan kepala keluarga yang memiliki nomor induk pasien. Sistem yang diusulkan keluarga pasien seharusnya mempunyai nomor pasien terpisah dengan kepala keluarganya.

Ketujuh, hambatan dalam pelayanan kesehatan, pengelolaan data medik pasien, maupun data administrasi yang dimiliki oleh klinik, sehingga mengakibatkan redudansi data, unintegrated data, human error, dan terlambatnya informasi. Dengan terbentuknya sistem informasi, diharapkan hambatan-hambatan tersebut tidak akan terjadi lagi.

\section{DAFTAR PUSTAKA}

Efraim, Turban, Rainer R. Kelly, Jr., dan Richard E. Potter. (2003). Introduction to Information Technology, $2^{\text {nd }}$ Edition. USA: John Wiley \& Sons, Inc.

Hartono, Jogiyanto. (1999). Analisis dan Desain Sistem Informasi: Pendekatan Terstruktur Teori dan Praktik Aplikasi Bisnis, Edisi kedua. Yogyakarta: Andi.

Jeffrey L., Whitten, Bentley Lonnie D., dan Ditman Kevin C. (2001). System Analysis and Design Method, $5^{\text {th }}$ Edition. New York: Mcgraw-Hill.

Jones, Frederick L., dan Dasartha V. Rama. (2006). Accounting Information Systems, International Student Edition. Canada: Thomson South-western.

Kepmenkes Republik Indonesia No 560/MENKES/SK/ IV/2003.

Konsil Kedokteran Indonesia. (2006).

Mathiasen, Lars. et al. (2000). Object Oriented Analysis and Design, $1^{\text {st }}$ Edition. Aalborg, Denmark: Marko Publishing ApS.

Mcleod, Raymond Jr. (2001). Management Information System, $8^{\text {th }}$ Edition. New Jersey: Prenticce Hall.

Misbahuddin. Gambaran Prosedur Sistem Informasi Manajemen Rekam Medis Unit Gawat Darurat Rumah Sakit di Indonesia, Jurnal Spektrum Vol.6, No. 2, hlm. 167-174, ISSN 1693-9573. Riau: PDPTS.

O'brien, James A. (2003). Introduction to Information Systems: Essentials for the e-Business Enterprise, $12^{\text {th }}$ Edition. New York: McGraw Hill.

Olson, David L. (2004). Introduction to Information System Project Management, $2^{\text {nd }}$ Edition. New York: McGraw Hill.

Wardiana, Wawan. (2002). Perkembangan Teknologi Informasi di Indonesia. Bandung: Lembaga Ilmu Pengetahuan Indonesia Bandung.

http://alexbudiyanto.web.id/2006/07/26/his-hospitalinformation-system.html, "HIS (Hospital Information System).

http://centaur8.multiply.com/journal/item/1/Sistem Informasi_Manajemen_Rumah_Sakit.

http://id.wikipedia.org/wiki/Rumah_sakit.

h t t p : / / m i d y u.s pa ce s. 1 i v e . c o m/b log/ cns!2D22F9BCA7FA8828!789.entry.

http:/www.astaqauliyah.com/2007/10/04/rekam-medisdefenisi-dan-kegunaannya.

http://www.forikes.webs.com, Jurnal Penelitian Kesehatan Suara, Nomor ISSN : 2086-3098.

http://www.informatika.lipi.go.id/perkembangan-teknologiinformasi-di-indonesia.

http://www.ramlibidullah.wordpress.com, Jurnal KesMas FKM, Nomor ISSN : 2086-3772. 